DOI https://doi.org/10.18551/rjoas.2020-11.09

\title{
FACTORS AFFECTING DEMAND FOR SOUTH KALIMANTAN SHRIMP EXPORT TO THE EUROPEAN UNION
}

\author{
Lilimantik Emmy \\ Department of Fishery Agribusiness, Faculty of Fisheries and Marine, \\ University of Lambung Mangkurat, South Kalimantan, Indonesia \\ E-mail: emmy.lilimantik@ulm.ac.id
}

\begin{abstract}
This study aims to determine the factors that affect the demand for South Kalimantan shrimp exports to the European Union. The data used are secondary data, namely time series data from 2006 to 2019. The research site is determined by purposive sampling which at PT. Karimata Timur with the consideration that this company is the only company in South Kalimantan that exports shrimp to the European Union. The analysis used is multiple linear regression analysis with the results of the analysis showing that (a) the X1 value of -21.191 explains that every $100 \%$ increase in the price of shrimp exports to the European Union will reduce the demand for shrimp exports from South Kalimantan to the European Union by $21.191 \%$, (b) The X2 value of $-14,339$ indicates that each $100 \%$ increase in the export price of shrimp to the non-European Union will reduce the demand for South Kalimantan shrimp exports to the European Union by $14.339 \%$ and (c) The X3 value of 57,867 indicates that every increase in the rupiah exchange rate is $100 \%$ will increase the demand for South Kalimantan shrimp exports to the European Union by $57.867 \%$ or if the rupiah strengthens against the US dollar (appreciation) then the demand for South Kalimantan shrimp exports by the European Union will increase, but on the other hand, if the rupiah weakens (depreciation) then the export demand by the European Union will decrease.
\end{abstract}

\section{KEY WORDS}

Shrimp, export, demand, price, rupiah exchange rate, the European Union.

The potential of the fisheries and marine sector in South Kalimantan is abundant, namely with a coastline of $1,330 \mathrm{~km}$ and public waters of one million hectares. From these marine and public waters, throughout 2018, 240,900 tons of capture fisheries have been produced. In addition to fishing businesses, fishery cultivation businesses are also developing, covering an area of around 60 thousand hectares, consisting of fishponds, ponds and minapadi businesses, as well as fishing cages and floating nets in public waters. Mina padi (from mina = "fish" and rice) is a form of combined farming which utilizes stagnant water from the paddy fields being planted with rice as a pond for cultivation that maximizes the yield of paddy fields. Production achieved from cultivation is 127,248 tons, with commodities including shrimp, milkfish, crab, tilapia, goldfish, catfish, pomfret, and others (Diskanlut, 2019). Apart from meeting domestic market demand, this fishery product is also used to fulfill foreign market demand.

Table 1 - South Kalimantan Fishery Export Volume, 2010 - 2014

\begin{tabular}{|c|c|c|c|c|c|c|c|c|c|c|}
\hline \multirow{3}{*}{ Export Commodities } & \multicolumn{10}{|c|}{ Export Volume Year (ton) } \\
\hline & \multicolumn{2}{|l|}{2010} & \multicolumn{2}{|l|}{2011} & \multicolumn{2}{|l|}{2012} & \multicolumn{2}{|l|}{2013} & \multicolumn{2}{|l|}{2014} \\
\hline & UE & NUE & UE & NUE & UE & NUE & UE & NUE & UE & NUE \\
\hline Shrimp & 148,5 & 1308,5 & 149,1 & 1384,9 & 63,1 & 1351,5 & 141,0 & 1382,4 & 53,8 & 1621,7 \\
\hline Others & - & 19,7 & - & 15,9 & - & 9,1 & - & 18,8 & - & 49,4 \\
\hline Amount & 148,5 & 1328,2 & 149,1 & 1400,8 & 63,1 & 1360,6 & 141,0 & 1401,2 & 53,8 & 1671,1 \\
\hline
\end{tabular}

Note: $E U$ = the European Union; NUE = Non-European Union; Source: LPPMHP (2015).

South Kalimantan fishery commodities such as tilapia, goldfish, catfish, pomfret, and others are still mostly used to meet consumer demand in South Kalimantan and parts of 
Kalimantan, while turtles, sea turtles, and shrimp have been used as export commodities. Shrimp exports dominated more than $97 \%$ of the total fishery export volume in South Kalimantan during the period 2010 - 2014 as shown in Table 1.

The fishery products of South Kalimantan which are exported are dominated by shrimp, the rest are other commodities such as turtles and shrimp heads. The volume of shrimp exports in South Kalimantan seems to have tended to continue to increase, except in 2012 that had experienced a decline, but again increased in the following year. The export destinations of South Kalimantan shrimp are divided into two groups, namely the European Union (countries in Europe) and the Non-European Union (countries in Asia). The exported shrimps consist of species of tiger prawns (Penaeus monodon), white shrimp (Penaeus indicus), pink shrimp (Metapenaeus affinis), pink kojek shrimp (Metapenaeus ensis) and yellow shrimp (Metapenaeus brevicornis). Raw material for frozen shrimp comes from the production of fresh shrimp, namely from marine fishing activities and aquaculture activities. The global economic crisis has caused export destination countries to tend to be more selective with regard to the quality of their exported products, including shrimp. Exporting countries are asked to provide quality raw materials, both in terms of size, product physical and microbiological content of shrimp.

Shrimp exports in South Kalimantan are run by private companies. Currently there are five shrimp exporting companies, namely PT. Karimata Timur with destination countries Japan, Hong Kong, Belgium, Holland, and Great Britain (Grade A); PT. Misaja Partners with destination countries Japan, Hong Kong, and Vietnam (Grade B); PT. Wirontono Baru with destination countries Japan and China (Grade B); PT. Ebimas Besar with destination countries Taiwan and Hong Kong (Grade B); and PT. Kalimantan Fishery with destination countries Japan, Thailand, Vietnam, Korea, and China (Grade B) (LPPMHP, 2017).

The European Union is one of the potential markets for Indonesian shrimp exports, with the large demand for the 2004-2016 period which can be seen in Figure 1.
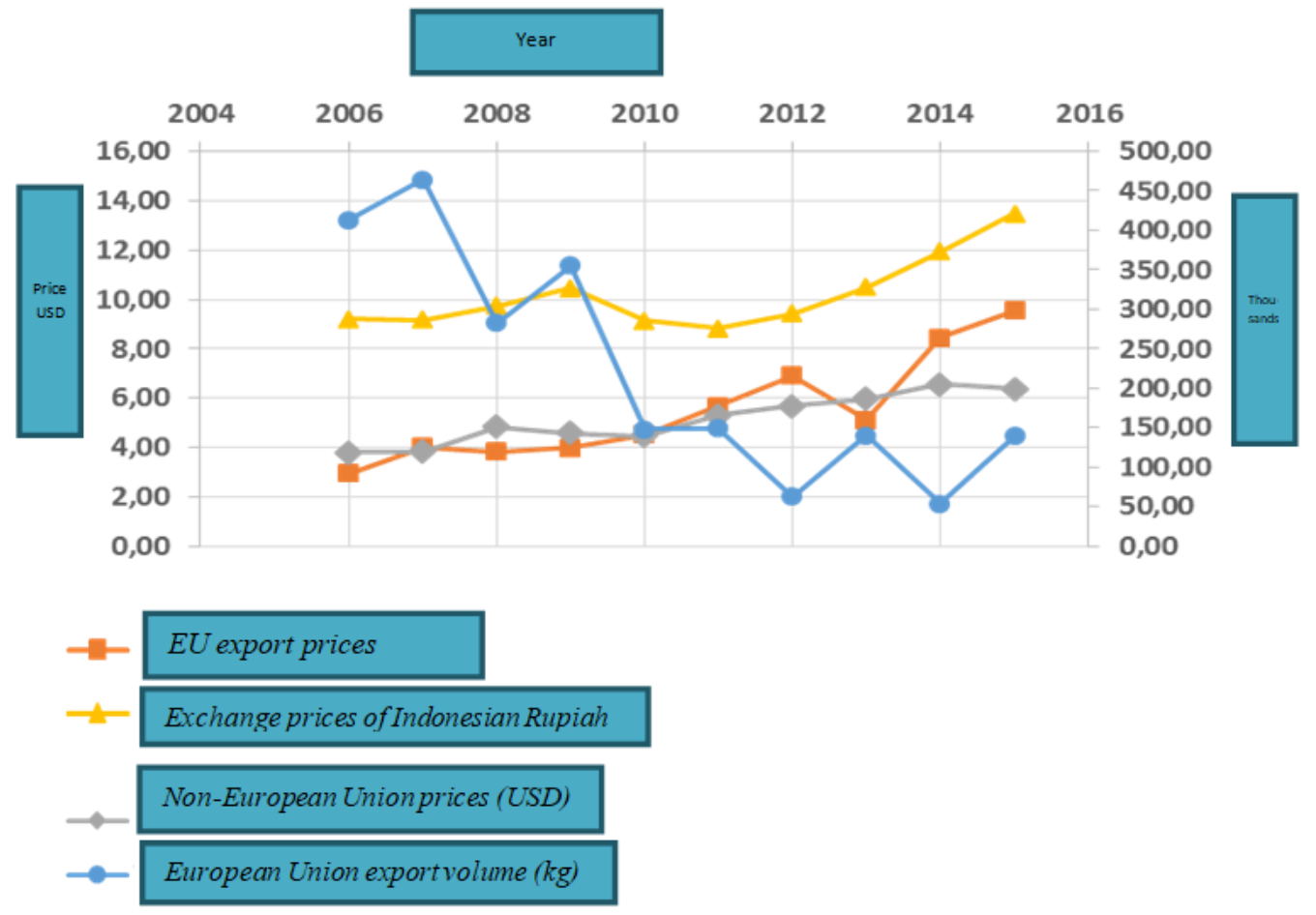

Figure 1 - Graph of Demand for South Kalimantan Shrimp Exports to the European Union in the period 2004-2016

Figure 1 shows that the demand for South Kalimantan shrimp exports to the European Union fluctuates with a downward trend, where this condition is inversely proportional to the export price which tends to continue to increase. This was followed by the trend of increasing 
export prices to non-EU countries and the weakening trend of the rupiah against the US dollar. This fact indicates that the increase in the export price of shrimp both to the European Union and non-EU resulted in decreased export demand by buyers to the European Union, and then exporters shifted their exports to non-European Union, especially production and export costs which tend to increase as a result of the weakening of the rupiah against US dollars.

One of the factors that influence shrimp exports is the international price of shrimp where the price continues to fluctuate from year to year. International shrimp prices have undergone several sharp price changes during 2005 to 2014. During 2005 to 2008, the international price of shrimp was always recorded at above $10 \mathrm{US} \$ / \mathrm{kg}$. Meanwhile in 2009, the international price of shrimp fell to 9.45 US \$ / kg (Mohani VC, Yulianto E, Mawardi MK, 2016). In addition, the rupiah exchange rate also affects the condition of Indonesia's shrimp exports. The weakening and strengthening of the rupiah exchange rate against the US dollar will cause the export price of shrimp to rise and fall so that Indonesian shrimp exports will also have an effect. The strengthening of the rupiah currency against the US dollar will cause a decline in Indonesian exports (Ginting, 2013).

\section{METHODS OF RESEARCH}

This research was conducted for 4 months from January to April 2020, while the research location was determined by purposive sampling at PT. Karimata Timur with the consideration that this company is the only company in South Kalimantan that exports shrimp to the European Union.

The data used are secondary data sourced from the bookkeeping of sample companies including data on shrimp export volume to the European Union, shrimp export prices to the European Union, and shrimp export prices to non-EU countries; statistics on the exchange rate of the US dollar currency at Bank Indonesia; and other supporting data obtained from various sources. The data collected is time series data per year from 2006 to 2019 (14 years).

The factors that determine the demand for South Kalimantan shrimp exports to the European Union are analyzed using the Multiple Linear Regression equation model with the formula:

$$
\ln Y=a+b_{1} \ln X_{1}+b_{2} \ln X_{2}+b_{3} \ln X_{3}+u_{i}
$$

Where:

- $\quad \mathrm{Y}=$ volume of shrimp exports to the European Union $(\mathrm{kg})$;

- $\mathrm{X}_{1}=$ export price of shrimp to the European Union (USD/kg);

- $\mathrm{X}_{2}=$ export price of shrimp to non-EU (USD/kg);

- $\mathrm{X}_{3}=$ rupiah exchange rate $(\mathrm{Rp} / \mathrm{USD})$;

- $\mathrm{a}=$ constant;

- $\mathrm{b}=$ regression coefficient;

- $u_{i}=$ error (disturbance term).

To test the equation model (1), the $\mathrm{F}$ test is used with the following formula:

$$
F_{\text {hit. }}=\frac{J K_{\text {reg }} /(k-1)}{J K_{\text {sisa }} /(n-k)}
$$

Where: $J K=$ sum of square; $k=$ number of variables; $n=$ number of data.

With the hypothesis: $\mathrm{H}_{0}: b_{1}=\ldots . .=b_{i}=0 ; \mathrm{H}_{1}$ : one or more $b_{i} \neq 0$.

The test criteria are:

- When the probability value or $|\mathrm{p}|>\alpha 0.05$; then $\mathrm{HO}$ is accepted, which means that simultaneously the independent variable has no significant effect on the dependent variable; 
- When the value $|\mathrm{p}|<\alpha 0.05$; then $\mathrm{H} 0$ is rejected, which means that simultaneously the independent variable has a significant effect on the dependent variable.

To determine whether there is an effect of each independent variable individually on the dependent variable, the $t$ test is used with the formula:

$$
t_{\text {hit. }}=\frac{b_{i}}{S_{b i}}
$$

Where: $b_{i}=$ regression coefficient; $S_{b i}=$ standard error of regression coefficient; $i=$ independent variable $X_{1}, X_{2}, X_{3}$.

Hypothesis: $\mathrm{H}_{0}: b_{i}=0 ; \mathrm{H}_{1}: b_{i} \neq 0$.

Decision criteria:

- If $|p|>\alpha_{0,05}$; then $\mathrm{HO}$ is accepted, which means that changes in each independent variable have no significant effect on changes in the dependent variable;

- If $|p| \leq \alpha_{0,05}$; then $\mathrm{HO}$ is rejected, which means that changes in each independent variable have a significant effect on changes in the dependent variable.

\section{RESULTS AND DISCUSSION}

A regression analysis that estimates the relationship of export demand $(Y)$ with each variable factor (independent variable, $\mathrm{Xi}$ ), produces a value as shown in Table 2.

Table 2 - Results of Regression Analysis of Factors Affecting Demand for Export of South Kalimantan Shrimp to the European Union

\begin{tabular}{|c|c|c|}
\hline No. & Description & Scores \\
\hline 1. & R Square & 0,854 \\
\hline 2. & Observations & 14 \\
\hline 3. & $\mathrm{X} 1$ & $-21,191$ \\
\hline 4. & $\mathrm{X} 2$ & $-14,339$ \\
\hline 5. & $\mathrm{X} 3$ & 57,867 \\
\hline
\end{tabular}

Source: Primary data processed (2020).

The regression equation is then transformed into $\mathrm{X}$ form, so that the following equation is obtained:

$$
Y=13,2194-21,191 X_{1}-14,339 X_{2}+57,867 X_{3}
$$

The coefficient of determination (R2) is 0.854 which means that the variation in $Y$ change can be explained by the $\mathrm{Xi}$ variable specified in the model of $0.854 \%$, the remaining $14.666 \%$ is another variable that is not clearly specified in the model. This shows that there is a close relationship between the demands for South Kalimantan shrimp exports to the European Union. A constant value of 13,220 explains that if all the variable factors (Xi variable) are constant or equal to zero, the demand for South Kalimantan shrimp exports to the European Union will be $13,220 \%$.

The probability value | $p \mid 0.040<0.05$ in the variable price of shrimp exports to the European Union (X1) indicates that changes in this variable cause a significant change in export demand at the test level of $95 \%$. Thus, accept $\mathrm{H} 1$ and reject $\mathrm{H} 0$, which means that changes in $\mathrm{X} 1$ have a significant effect on changes in $\mathrm{Y}$.

The regression coefficient $\mathrm{X} 1$ is -21.191 , indicating that every $100 \%$ increase in the export price of South Kalimantan shrimp to the European Union will reduce the demand for South Kalimantan shrimp exports to the European Union by $21.191 \%$ or vice versa, if the other independent variables are constant. These results indicate that the price elasticity of South Kalimantan shrimp exports to the European Union is inelastic, because the percentage change in export demand is smaller than the percentage change in the selling price. 
Value | $p$ | $0.040<0.05$ in the non-EU shrimp export price variable (X2) indicates that changes in this variable cause a significant change in demand for shrimp exports to the European Union at the 95\% test level. For that, accept $\mathrm{H} 1$ and reject $\mathrm{H} 0$, which means that changes in $\mathrm{X} 2$ have a significant effect on changes in $\mathrm{Y}$.

The regression coefficient $X 1-14,339$ shows that every $100 \%$ increase in the export price of shrimp from South Kalimantan to the non-European Union will reduce the demand for South Kalimantan shrimp exports to the European Union by $14.339 \%$ or vice versa, if the other independent variables are constant. This indicates a very close relationship between shrimp exported to the European Union and those exported to non-EU countries, because the value of the cross elasticity $(14,339)$ is far from zero.

According to Soekartawi (1987), if the cross elasticity of an item against another is positive, the relationship between the two goods is mutually substituted (substitution), on the other hand, if it is negative, then the two are complementary (complementary). Thus, the negative sign in the regression coefficient shows that the relationship between shrimp exported to the European Union and those exported to non-EU in South Kalimantan fishery exports are complementary, so that even though the export prices of the two commodities have changed, the exports of both will continues in accordance with consumer needs.

Value | $p$ | $0.040<0.05$ in the rupiah exchange rate variable (X3) indicates that the change in this variable causes a significant change in the demand for South Kalimantan shrimp exports to the European Union at the 95\% test level. Thus, accept $\mathrm{H} 1$ and reject $\mathrm{H} 0$, which means that changes in $\mathrm{X} 3$ have a significant effect on changes in $\mathrm{Y}$.

The regression coefficient $X 3$ is 57,867 , indicating that every $100 \%$ increase in the rupiah exchange rate will increase the demand for shrimp exports from South Kalimantan to the European Union by $57.867 \%$ or vice versa, if the other independent variables are constant. In other words, if the rupiah strengthens against the US dollar (appreciation) then the demand for South Kalimantan shrimp exports by the European Union will increase, but on the other hand, if the rupiah weakens (depreciates) the export demand by the European Union will decrease.

The European Union's request to export South Kalimantan shrimp in the form of cooked shrimp requires a higher processing cost than frozen shrimp. Exporters prefer to export more shrimp to the European Union when the rupiah increases because it may be considered more profitable. Kholifin (2013) said that the strengthening of the rupiah against the US dollar also increased the demand for Indonesian frozen shrimp exports to the European Union.

\section{CONCLUSION}

The X1 value of -21.191 indicates that every $100 \%$ increase in the export price of South Kalimantan shrimp to the European Union will reduce the demand for South Kalimantan shrimp exports to the European Union by $21.191 \%$, this indicates that the elasticity of the export price of shrimp from South Kalimantan to the European Union is inelastic, because the percentage change in export demand is smaller than the percentage change in the selling price.

The X2 value of -14.339 indicates that every $100 \%$ increase in the export price of shrimp from South Kalimantan to the non-European Union will reduce the demand for South Kalimantan shrimp exports to the European Union by $14.339 \%$ or vice versa, if the other independent variables are constant. This indicates a very close relationship between shrimp exported to the European Union and those exported to non-EU countries, because the value of the cross elasticity $(14,339)$ is far from zero.

The X3 value of 57,867 indicates that every $100 \%$ increase in the rupiah exchange rate will increase the demand for South Kalimantan shrimp exports to the European Union by $57.867 \%$ or vice versa, if the other independent variables are constant. In other words, if the rupiah strengthens against the US dollar (appreciation) then the demand for South Kalimantan shrimp exports by the European Union will increase, but on the other hand, if the rupiah weakens (depreciation) the export demand by the European Union will decrease. 


\section{REFERENCES}

1. Arini, S.D. 2010. Analisis Permintaan Ekspor Udang Beku Kalimantan Selatan. Program Studi Magister Ilmu Perikanan. Program Pascasarjana. Universitas Lambung Mangkurat, Banjarbaru.

2. Asymunir. 2006. Analisis Permintaan Ekspor Udang Indonesia. Program Studi Ekonomi Pertanian. Pascasarjana. Universitas Gadjah Mada, Yogyakarta.

3. Badan Standarisasi Nasional. 2006. Udang Kupas Rebus Beku: Penanganan and Pengolahan. Badan Standarisasi Nasional, Jakarta.

4. BPS. 2016. Kalimantan Selatan dalam Angka 2015. Badan Pusat Statistik Provinsi Kalimantan Selatan, Banjarmasin.

5. Dahuri, R. 2002. Paradigma Baru Pembangunan Indonesia Berbasis Kelautan. Orasi IImiah. IPB, Bogor.

6. Diskanlut. 2017. Laporan Tahunan Statistik Perikanan Tangkap and Budidaya Kalimantan Selatan Tahun 2016. Dinas Perikanan and Kelautan Provinsi Kalimantan Selatan, Banjarbaru.

7. Gujarati, D.N. 2009. Dasar-Dasar Ekonometrika. Penerbit Erlangga, Jakarta.

8. Hady, H. 2001. Ekonomi Internasional: Teori and Kebijakan Perdagangan Internasional. Ghalia Indonesia, Jakarta.

9. Halwani, H. 2005. Ekonomi Internasional and Globalisasi Ekonomi. Edisi Kedua. Ghalia Indonesia, Jakarta.

10. Hanafiah, A.M. and A.M. Saefudin. 1986. Tata Niaga Hasil Perikanan. Penerbit Universitas Indonesia, Jakarta.

11. Jhingan, M.L. 2000. Ekonomi Pembangunan and Perencanaan. Terjemahan: D. Guritno. Edisi Pertama. PT. Raja Grafindo Persada, Jakarta.

12. Kholifin, M.B. 2013. Determinan Permintaan Ekspor Udang Beku Indonesia ke Uni Eropa. Skripsi. Jurusan Ekonomi Pembangunan. Fakultas Ekonomi. Universitas Negeri Semarang, Semarang.

13. KKP. 2014. Statistik Kelautan and Perikanan. Kementerian Kelautan and Perikanan Republik Indonesia, Jakarta.

14. Kohl, R.L. and J.N. Uhl. 1990. Marketing of Agricultural Products. Mac Millan Publishing Company, New York.

15. Krugman, P.R. and O. Maurice. 2005. Ekonomi Internasional: Teori and Kebijakan. Gramedia, Jakarta.

16. Lipsey, R.G. 1995. Pengantar Mikroekonomi. Edisi Kesepuluh. Binarupa Aksara, Jakarta.

17. LPPMHP. 2015. Laporan Tahunan Laboratorium Pengujian and Pembinaan Mutu Hasil

18. Perikanan (LPPMHP) Banjarbaru Tahun 2014. Dinas Perikanan and Kelautan Kalimantan Selatan. Laboratorium Pengujian and Pembinaan Mutu Hasil Perikanan (LPPMHP), Banjarbaru.

19. 2016. Laporan Tahunan Laboratorium Pengujian and Pembinaan Mutu Hasil Perikanan (LPPMHP) Banjarbaru Tahun 2015. Dinas Perikanan and Kelautan Kalimantan Selatan. Laboratorium Pengujian and Pembinaan Mutu Hasil Perikanan (LPPMHP), Banjarbaru.

20. Mankiw, N.G. 2000. Teori Makroekonomi. Edisi Keempat. Erlangga, Jakarta.

21. Montgomery, D.C. and G.C. Runger. 2003. Applied Statistics and Probability for Engineers. Third Edition. John Wiley \& Sons, Inc. New York.

22. Nopirin. 2001. Ekonomi Internasional. BPFE, Yogyakarta.

23. Pusat Karantina Ikan. 2014. Persyaratan Ekspor Hewan Akuatik ke Uni Eropa. BKIPM. Pusat Karantina Ikan, Jakarta.

24. Setyaningtyas, W.R. 2005. Analisis Pengendalian Kualitas Produksi Pembekuan Udang PT. Istana Cipta Sembada dengan Menggunakan Diagram Kontrol C. Universitas Negeri Semarang. Fakultas Matematika and IImu Pengetahuan Alam, Semarang.

25. Simamora, S. D. 2014. Langkah and Strategi Ekspor ke Uni Eropa: Produk Udang. APINDO-EU ACTIVE, Jakarta.

26. Soekartawi. 1987. Prinsip Dasar Ekonomi Pertanian. Teori and Aplikasinya. Penerbit Rajawali Press, Jakarta. 
27. Stanton, W.J. 1994. Fundamental of Marketing. International Book Company, Singapore. 28. Sudjana. 1992. Metoda Statistika. Penerbit Tarsito, Bandung.

29. Sukirno, S. 2005. Pengantar Teori Mikroekonomi. Edisi Ketiga. PT. RajaGrafino Persada, Jakarta.

30. Todaro, M.P. and S.C. Smith. 2003. Pembangunan Ekonomi di Dunia Ketiga. Edisi Kedelapan. Erlangga, Jakarta.

31. Triyoso, B. 1984. Model Ekspor Non Migas Indonesia dalam Proyeksi Pendek. Majalah Ekonomi and Keuangan No. 2 Vol. XXXII, Jakarta.

32. Tandjung, Marolop (2011), Aspek and Prosedur Ekspor-Impor, Jakarta: Salemba Empat.

33. Ginting, Ari Mulianta (2013), Pengaruh Nilai Tukar Terhadap Ekspor Indonesia. Bulletin Ilmiah Litbang Perdagangan, Vol. 7 No. 1, pp. 1-18.

34. Mohani VC, Yulianto E,Mawardi MK, 2016. Pengaruh Jumlah Produksi Udang Indonesia, Harga Udang Internasional, and Nilai Tukar Rupiah Terhadap Ekspor Udang Indonesia (Studi Volume Ekspor Udang Indonesia Tahun 2005-2014). Jurnal Administrasi Bisnis (JAB) Vol. 39 No.2 Oktober 2016| administrasibisnis.studentjournal.ub.ac.id. 